\title{
Design and Build A Photovoltaic and Vertical Savonious Turbine Power Plant as an Alternative Power Supply to Help Save Energy in Skyscrapers
}

\author{
Dadang Priyambodo ${ }^{1}$, and Anggara Trisna Nugraha ${ }^{1}$ \\ ${ }^{1}$ Marine Electrical Engineering Shipbuilding Institute of Polytechnic Surabaya, Surabaya, Jl. Teknik Kimia Keputih Sukolilo, Surabaya 60111, Indonesia
}

Corresponding Author: Dadang Priyambodo (dpriyambodo@student.ppns.ac.id)

\begin{abstract}
Indonesia is a tropical country, because its area that crosses the equator has enormous solar potential, with a radiation magnitude of $4.80 \mathrm{kWh} / \mathrm{m} 2$ / day / day or equivalent to $112,000 \mathrm{GWp}$. Meanwhile, the solar energy received by the earth is $1.74 \times 1017 \mathrm{~W} /$ hour, of which about $1-2 \%$ is converted into wind energy. However, in terms of total energy potential, Indonesia only uses around $10 \mathrm{MWp}$ of solar energy, the difference is that wind energy which is planned to reach $250 \mathrm{MW}$ in 2025 only uses $1 \mathrm{MW}$ of the total potential. Skyscrapers are places with enormous wind energy potential. Because if the height exceeds $150 \mathrm{~m}$, the reference point of the building can be called a skyscraper, which will cause high wind speed at the top of the building. This phenomenon is caused by the influence of the friction force which suppresses the wind speed, therefore the higher the position, the higher the wind speed. With this potential, to provide additional power and help save energy in existing facilities in the building, a smart photovoltaic and vertical turbine prototype design was created. The prototype design is a combination of weathered turbines and solar panels, the reason for using this type of turbine is because it can rotate at low wind speed (low wind speed) and has a very simple structure. In addition, because it uses a vertical shaft, the generator and gearbox can be placed close to the ground, making maintenance easier. The working principle of this prototype is designed to use a turbine to convert wind energy on the roof of the building into electrical energy, then mix it with electrical energy converted from solar energy by solar panels, so that electrical energy will be more optimal.
\end{abstract}

INDEX TERMS: Electrification, Power plants, Renewable energy

\section{INTRODUCTION}

Indonesia's electricity demand continues to increase from year to year. To achieve the goal of increasing the electrification rate up to $100 \%$ by 2025 , by 2050 it is estimated that electricity demand will increase more than 7 times, reaching 1,611 TWh [1]. To meet the demand for electricity, the government has prepared a $35 \mathrm{GW}$ plan, namely up to s.d. 2015. National Medium Term Development Plan Document (RPJMN). 2019 [2]. When the plan was launched, economic and technical factors (such as the characteristics of a single power plant project) led to a slow increase in output [3]. Taking these factors into account, additional power generation will be carried out between 2015 and 2015. It is estimated that the installed capacity in 2019 is only $12 \mathrm{GW}$, well below the initial target of $35 \mathrm{GW}$
[4]. Currently, a power plant with COD (Commercial Operation Date) only operates around $4 \%( \pm 1.5 \mathrm{GW})$. In this case, it is hoped that the $35 \mathrm{GW}$ plan will be implemented from 2025 to 2026 [5]. In terms of increasing power generation, it is estimated that by 2025 coal-fired power plants will still reach $58 \%$ or around $50 \mathrm{GW}$ [6]. However, the existence of coal as a fuel for power plants is dwindling over time, and of course it cannot be renewed. According to BPPT, coal reserves in 2018 will be exhausted within 68 years. Therefore, to be able to continue to meet Indonesia's electricity needs, new innovations are needed [7]. One of them is by utilizing renewable energy which is abundant in nature.

Renewable energy sources that have great potential are wind energy and solar energy [7]. Indonesia has enormous wind 
energy potential, this is due to the monsoon phenomenon which is supported by Indonesia's territory, $70 \%$ of the country's territory is water (8). According to BPPT 2018, Indonesia's wind energy potential is $9.29 \mathrm{GW}$, and the utilization rate is around 0.0005 GW [9]. Skyscrapers are places with enormous wind energy potential. Because if the height exceeds $150 \mathrm{~m}$, the reference point of the building can be called a skyscraper, which will cause high wind speeds above the building. This phenomenon is caused by friction which limits wind speed, so that the higher the position, the higher the wind speed [10]. With this potential, to provide additional power and help save energy in existing facilities in the building, a smart photovoltaic prototype and vertical turbine was created [11]. Prototype design combined with weathered turbines [12] Like solar panels, this type of turbine is used because it can rotate at low wind speed and has a very simple structure. In addition, because it uses a vertical shaft, the generator and gearbox can be placed close to the ground for easy maintenance.

The working principle of the prototype is to use a turbine to convert wind energy on the roof of the building into electrical energy, then mix it with electrical energy, then convert solar energy into electrical energy by solar panels. production. Optimization [13]. It has enormous wind energy potential. Because if the height exceeds $150 \mathrm{~m}$ [14] then the building's benchmark can be called a skyscraper [14], which makes the wind speed above the building very high [15]. This phenomenon is caused by the presence of friction that suppresses wind speed, so that the higher the position, the higher the wind speed. With this potential, to provide additional power and help save energy in the existing facilities in the building, a smart photovoltaic and vertical turbine prototype design was created. The prototype design combines weathered turbines and solar panels, This type of turbine is used because it can rotate at low wind speeds (low wind speeds) and has a very simple structure. In addition, because it uses a vertical shaft, the generator and gearbox can be placed close to the ground, making maintenance easier. The working principle of the prototype is designed by using a turbine to convert wind energy on the roof of the building into electrical energy, then mix it with electrical energy converted from solar energy through solar panels, so that electrical energy becomes more ideal.

\section{MATERIALS AND METHODS}

This chapter will introduce some literature reviews or brief references.

\section{A. TOOLS AND MATERIALS}

\section{Multimeter}

This tool is also called a multi function tester, which is a special tool for measuring electrical components. First measure the relationship between current (amperes), voltage (voltage), resistance (ohms) and circuit resistance. Based on these basic functions, this tool is commonly called an AVO meter (ampere, voltage, ohm). Multimeter is very important because it can check the condition of the circuit. Errors that occur can be identified with high accuracy. Therefore, the existence of this tool is very valuable for electronics experts. The tool is very light and easy to carry everywhere.

\section{Anemometer}

Anemometer is a measuring instrument with a unique shape. At first glance, the shape of this tool resembles decorations and children's toys. However, the shape of this tool should not be underestimated, because the function of this tool is very useful, especially if you already know the weather forecast. The way this tool works is very simple, almost the same as the windmill in the Netherlands. The test should be done outdoors. Then, the tool will move when blown by the wind. The propeller / roller will rotate towards the base. If more blades rotate, it means the wind is blowing. Conversely, if the anemometer does not move, there is no wind at all. There is a tool at the bottom of the anemometer, which can calculate the wind speed in 1 second. 3. Light

The lamp is a lamp that is similar to a bottle, and the cavity of the lamp contains thin wires that can cause errors when connected to an electric current. In this study the lamp will be used as a test load.

4. Stopwatch

A lamp is a lamp that is shaped like a bottle with a filament in the cavity of the lamp, which can cause errors when connected to an electric current. In this study the lamp will be used as a test load.

\section{B. VERTICAL AXIS WIND TURBINE}

The vertical axis wind turbine (TASV) is a wind turbine with a vertical axis. This type of wind turbine is suitable for areas where the wind speed is less than $5 \mathrm{~m} / \mathrm{s}$ [8]. In addition, the required installation costs are lower than the cost of installing a horizontal axis wind turbine, and because of the low speed and small size of the turbine, the potential hazard of TASV is also less.

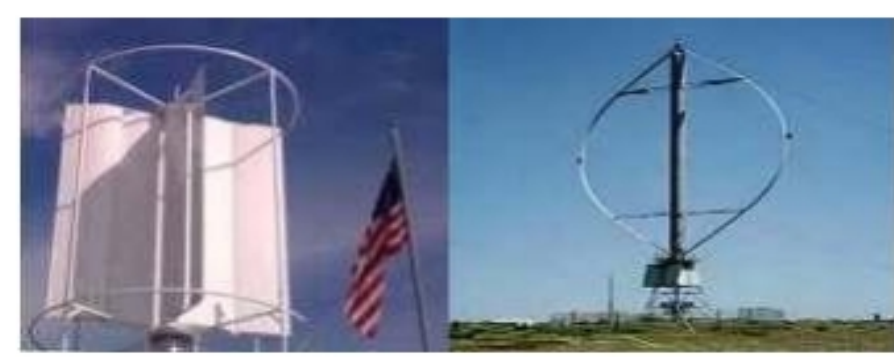

Fig. 1. VERTICAL Axis Wind Turbine (VAWT) [4]

\section{SOLAR PANEL}

Solar cells are the active elements that convert sunlight into electrical energy [9]. The minimum thickness of a solar cell is usually $0.3 \mathrm{~mm}$ and is made of a wedge of semiconductor material with positive and negative electrode covers. The basic principle of making solar cells is to use the photovoltaic effect, which can directly convert sunlight into electricity [10]. 


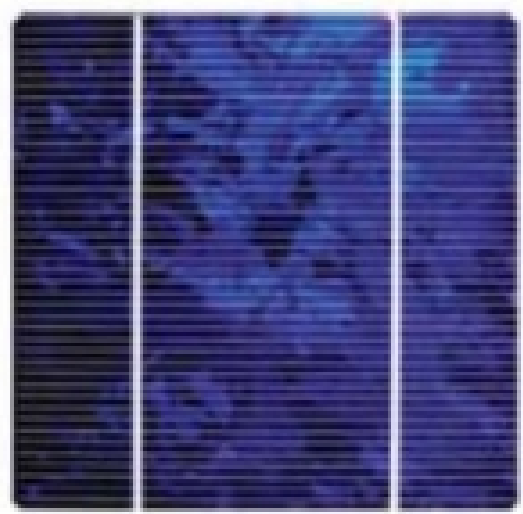

Fig. 2. Solar Panel [7]

\section{GEARS}

Gears are engine components that transmit rotation. According to the shape of the tooth path, gears can be divided into three categories: spur gears, helical gears and worm gears. Apart from continuous rotation or rotational transmission, gears can also be used as a medium to increase the number of revolutions. This can be achieved by applying different gear ratios. Find the turn ratio represented by the formula:

$$
i=\frac{z_{1}}{Z_{2}}
$$

where, $\mathrm{I}$ is transmission comparison, $\mathrm{z} 1$ is gear number of gear 1 , and $\mathrm{z} 2$ is gear number of gear 2

\section{E. SOLAR CHARGE CONTROL (SCC)}

SCC is an electronic device used to regulate the output of the solar panels to the battery. The goal is to avoid voltage instability and overcharging, which will shorten the battery life. The technology applied to SCC is pulse width modulation (PWM) technology. Apart from SCC, it can also be used to adjust the power supply from the battery to the load so that the battery does not overload or run out. SCC can be used to protect solar panels from battery backflow at night. The reason for this reverse current or reverse current is because the solar system does not charge the battery at night, which causes the solar panels to look like a load, and thus derives energy from the battery. If not resolved, the optoelectronic module itself will be damaged.

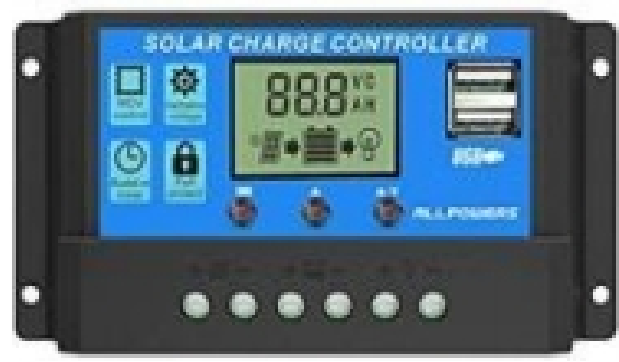

Fig. 3. Scc

\section{F. DESIGN CONCEPT}

After data collection and literature research, a design is carried out which includes mechanical design and electrical design. Following is the mechanical design of the hybrid power unit prototype.

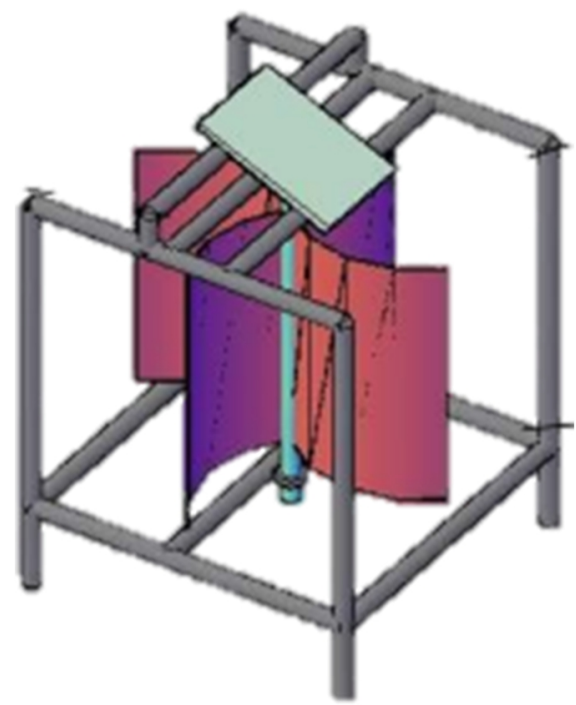

Fig. 4. The results of the prototype design

Next is the design of the electrical system.

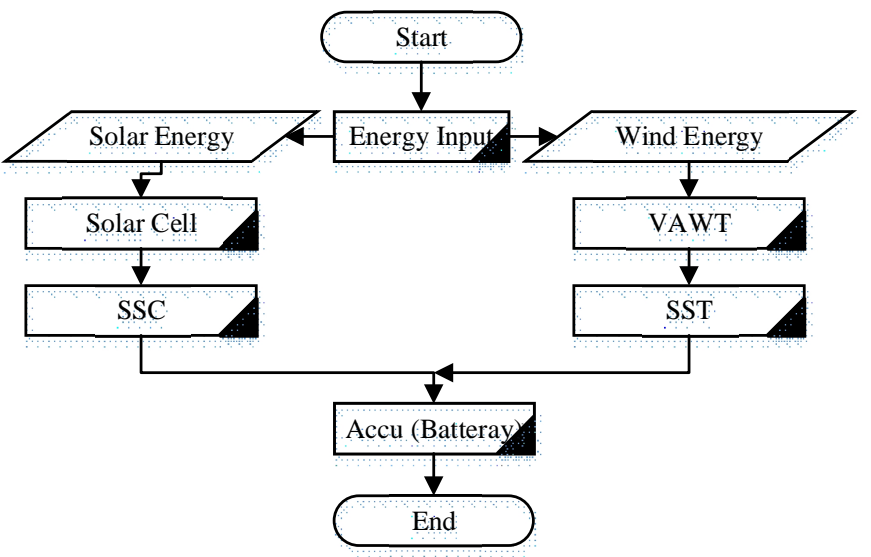

Fig. 5. Work system flow chart

The picture above shows a work plan which is divided into three parts, namely solar radiation and wind radiation input. Then there are vertical wind turbines, solar panels, charging equipment, and batteries. The last part is the DC output which can be used for DC loads and AC loads that must pass through the inverter first.

\section{RESULTS}

\section{A. WIND SPEED TESTING}

The test was carried out on the rooftop of Building J, State Shipping Polytechnic of Surabaya on October 2, 2019 which was conducted at $12.00 \mathrm{WIB}$. This test aims to determine the 
wind speed generated on top of the building J Surabaya State Marine Polytechnic which will then be used to design this prototype.

TABLE I. WIND SPEED TESTING

\begin{tabular}{cc}
\hline Time (hours) & Velocity $(\mathbf{m} / \mathbf{s})$ \\
\hline 11.00 & 2 \\
\hline 12.00 & 2,54 \\
\hline 13.00 & 3,1 \\
\hline 14.00 & 3,4 \\
\hline 15.00 & 3,6 \\
\hline 16.00 & 4,9 \\
\hline 17.00 & 5,1 \\
\hline
\end{tabular}

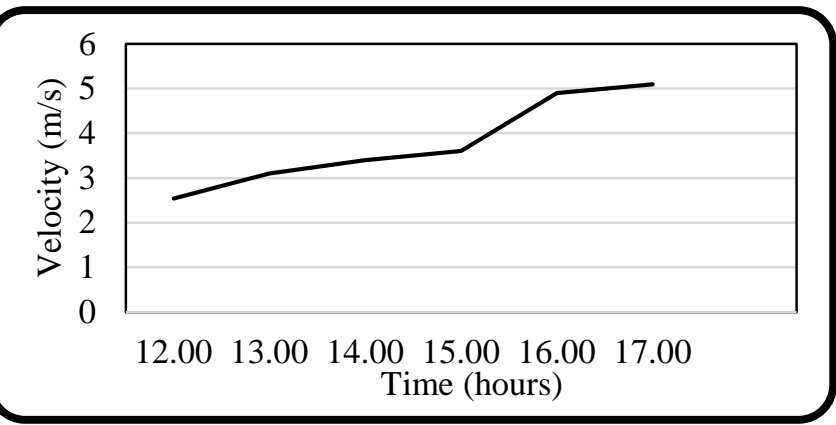

Fig. 6. Velocity measurement test

Use anemometer to test, this is to make the test get correct data. Test results are based on data, the average wind speed on the rooftop of $\mathbf{J}$ building of the Surabaya State Polytechnic is $3.67 \mathrm{~m} / \mathrm{s}$.

\section{B. WIND TURBINE TESTING}

This test aims to determine the amount of electrical power generated by wind energy with this prototype. The test was carried out on October 3, 2019 at the rooftop of building J, Surabaya State Marine Polytechnic with 4 speed variations. Test result data can be seen in the following table:

TABLE II.

POWER MEASUREMENT TEST OF THE TURBINE

\begin{tabular}{ccc}
\hline Time (Hours) & Voltage (Volt) & Current (mA) \\
\hline 11.00 & 7,015 & 289 \\
\hline 12.00 & 7,12 & 311 \\
\hline 13.00 & 7,111 & 332 \\
\hline 14.00 & 7,234 & 343 \\
\hline 15.00 & 7,15 & 323 \\
\hline 16.00 & 7,27 & 345 \\
\hline 17.00 & 7,28 & 378 \\
\hline
\end{tabular}

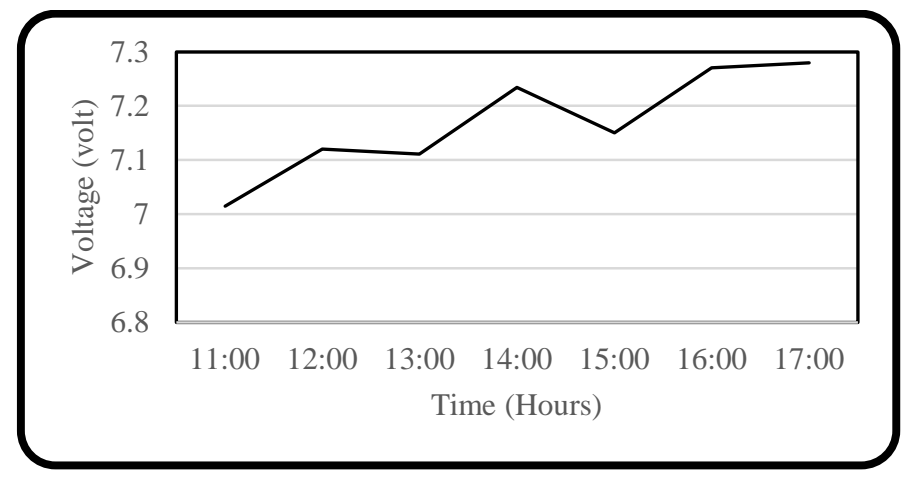

Fig. 7. Voltage measurement test

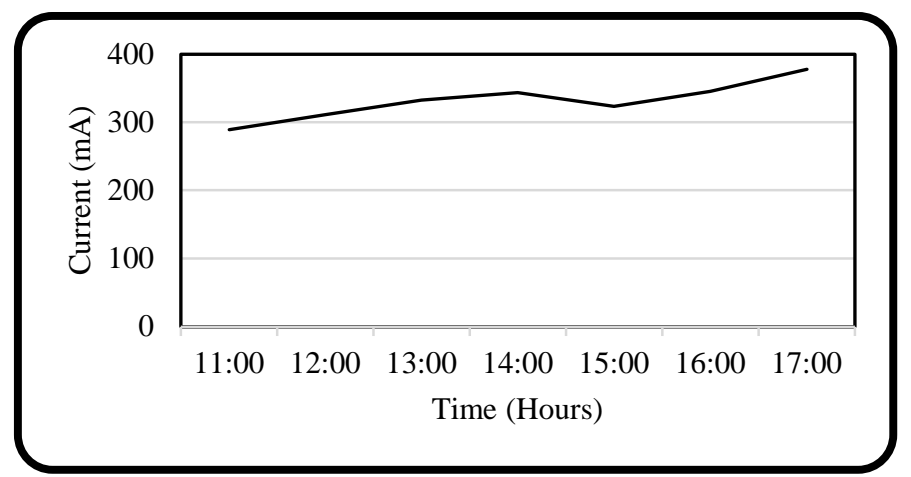

Fig. 8. Current measurement test

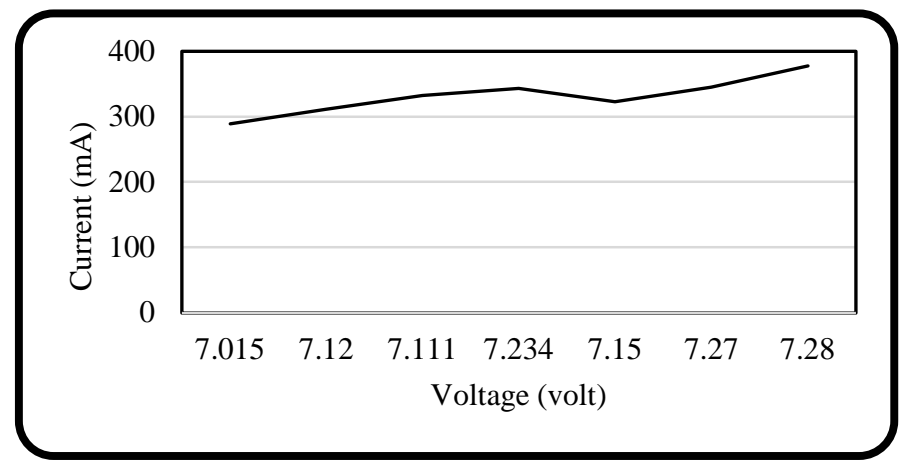

Fig. 9. Voltage and current relation

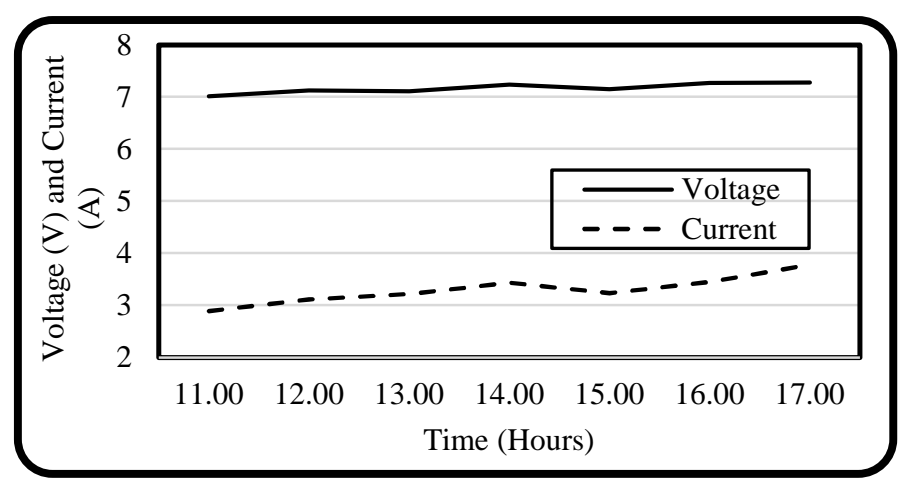

Fig. 10. Wind turbine test chart and current 
Based on the test data obtained, the average electric power is 2.1446 watts. In this test, the wind turbine uses a good wind speed because previously the wind turbine was designed with a wind speed of $4 \mathrm{~m} / \mathrm{s}$. The faster the wind speed, the greater the power generated.

\section{SOLAR PANEL TESTING}

At this stage, the test was carried out on August 29, 2019 at the rooftop of Building J, State Marine Polytechnic of Surabaya at 09.00-13.00. The purpose of this test is to determine the value of $24 \mathrm{~W}$ by calculating the tilt angle so as to determine the maximum electrical power that a $10 \mathrm{Wp}$ solar panel can produce. Use weight to measure strength. The load used is a DC lamp with a power of 5 watts. The test data are as follows:

TABLE III.

POWER MEASUREMENT TEST

\begin{tabular}{cccc}
\hline Time (Hours) & Voltage $(\mathbf{V})$ & Current $(\mathbf{A})$ & Power $(\mathbf{W})$ \\
\hline 09.00 & 15,12 & 0,57 & 8,61 \\
\hline 09.30 & 15 & 0,62 & 9,3 \\
\hline 10.00 & 15,6 & 0,51 & 7,95 \\
\hline 10.30 & 15,8 & 0,67 & 10,65 \\
\hline 11.00 & 15,92 & 0,61 & 9,58 \\
\hline 11.30 & 15,82 & 0,67 & 10,59 \\
\hline 12.00 & 15,87 & 0,66 & 10,32 \\
\hline
\end{tabular}

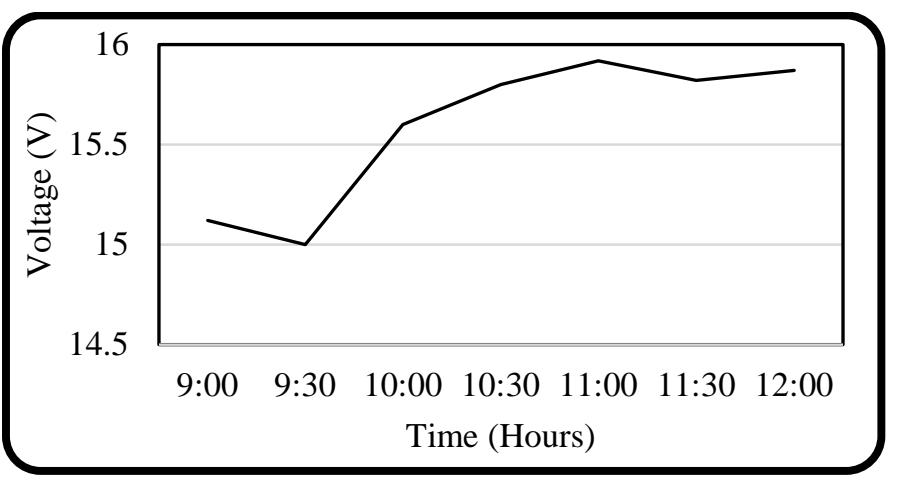

Fig. 11. Voltage and time corelation

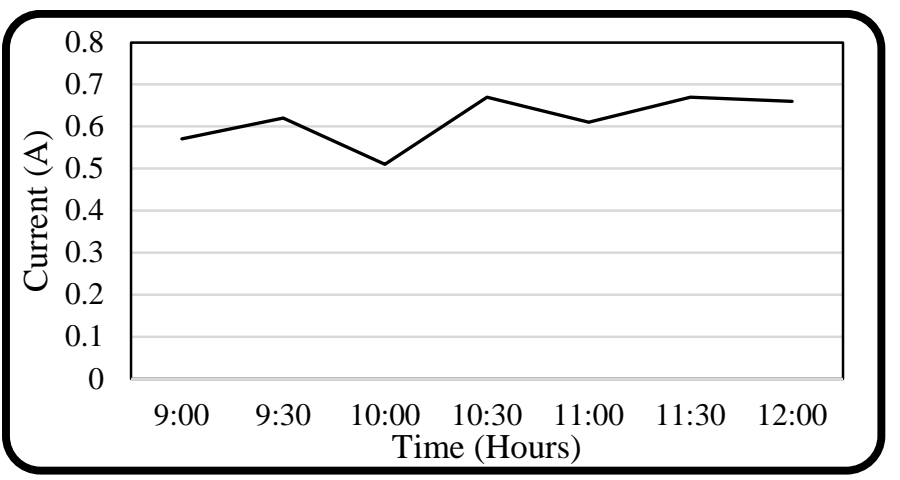

Fig. 12. Time and current (A) corelation

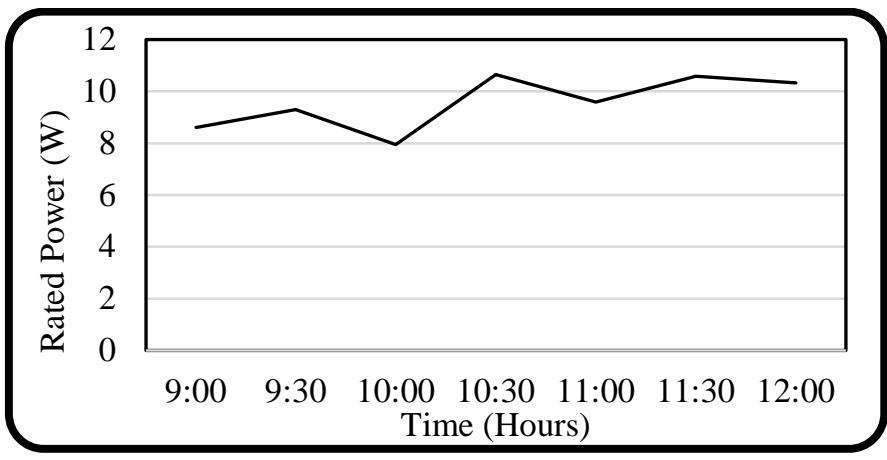

Fig. 13. Time and power corelation

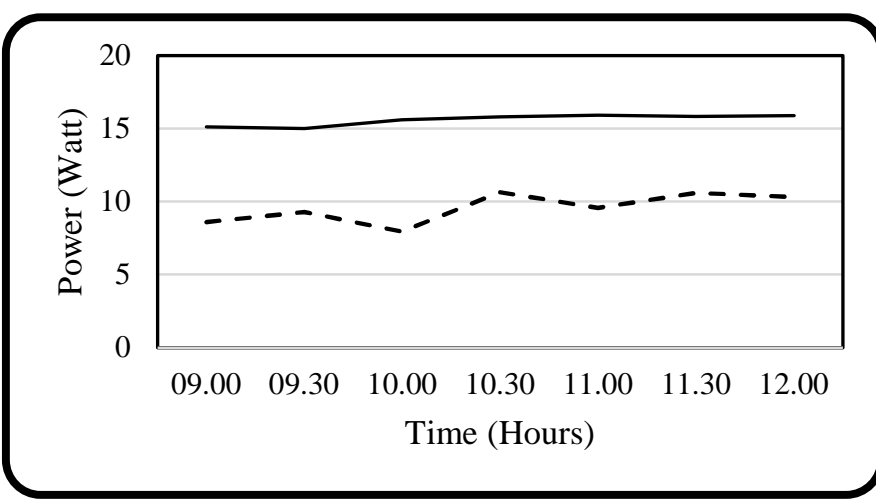

Fig. 14. Power measurement test

In solar panel testing, Arduino Uno R3 and LDR are used to collect light intensity data, so it is found that the higher the intensity of sunlight on the solar panel, the higher the resulting voltage and current, and vice versa. In this test, it was found that the average power produced was 9.37 watts.

\section{HYBRID CALCULATION}

Theoretically, by adding the power generated by the turbine to the power generated by the solar panels, the calculation results of the mixed data between turbines and solar panels can be obtained. By combining the power between the turbine and solar panels, it is found that the electric power obtained is also greater, and the calculated power is 11.55 watts.

\section{DISCUSSION}

In previous research, data obtained in the form of less than optimal output power. The factors that affect the inability to obtain optimal power output come from the calculation of equipment planning that has not been optimally realized, so this tool is not suitable for capturing its energy potential. Therefore, designing prototypes (smart photovoltaic and vertical turbines) as an alternative resource can help save energy in multi-storey buildings. In other words, the development result of existing hresearch is to maximize the potential of existing energy and utilize it to produce the best electricity as needed.

The use of a vertical axis on the turbine makes the design easy to apply anywhere, because the turbine does not have to point to the wind, so the turbine can be placed in a different wind 
direction. In this design, the generator speed increases as the gear ratio increases. Through the wind speed test equipment that has been carried out, it can be seen that the average wind speed above the Surabaya State Oceanic Technology Institute is $4 \mathrm{~m} / \mathrm{s}$. The higher the intensity of sunlight, the higher the voltage and current generated, and vice versa.

\section{CONCLUSION}

The use of a vertical axis on the turbine makes the design easy to apply anywhere, because the turbine does not have to point to the wind, so the turbine can be placed in a different wind direction. In this design, the generator speed increases as the gear ratio increases. Through the wind speed test equipment that has been carried out, it can be seen that the average wind speed above the Surabaya State Oceanic Technology Institute Building is $4 \mathrm{~m} / \mathrm{s}$. The higher the intensity of sunlight, the higher the voltage and current generated, and vice versa. The power produced by the design prototype is 11.55 watts.

\section{REFERENCES}

[1] D. P. AT Nugraha, "Development of Rocket Telemetry in Chamber Gas Pressure Monitoring with the MPXV7002DP Gas Pressure Sensor," Journal of Electronics, Electromedical Engineering, and Medical Informatics, 2020

[2] Tambunan, Robert Maraluli Tua., 2008. "Perancangan dan Pembutan Turbin Angin Sumbu Horizontal Dua Sudu Berdiameter $3.5 \mathrm{~m}$ dengn Modifikasi Pemotongan dan Pengaturan Sudut Pitch”. Dinamika Teknik Mesin, 3(1), 2013

[3] DeLuca, Carlo J., et al. "Biosignal monitoring system and method." U.S Patent No. 6,238,338. 29 May 2001.

[4] Sarkis, Joseph, and James J. Cordeiro. "Investigating technical and ecological efficiencies in the electricity generation industry: are there winwin opportunities?." Journal of the Operational Research Society 60, no. 9 (2009): 1160-1172.

[5] Caduff, Marloes, Mark AJ Huijbregts, Hans-Joerg Althaus, Annette Koehler, and Stefanie Hellweg. "Wind power electricity: the bigger the turbine, the greener the electricity?." Environmental science \& technology 46, no. 9 (2012): 4725-4733.

[6] El-Wakil, M., 1984. Power Plant Technology, International Edition. Hau, Erich. 2006. Wind Turbines Fundamentals, Technologies, Application, Economics. Edisi Kedua. Germany. Springer.

[7] Cheng, Ming, and Ying Zhu. "The state of the art of wind energy conversion systems and technologies: A review." Energy conversion and management 88 (2014): 332-347.

[8] Koutroulis, Eftichios, and Kostas Kalaitzakis. "Design of a maximum power tracking system for wind-energy-conversion applications." IEEE transactions on industrial electronics 53, no. 2 (2006): 486-494.

[9] D. P. AT Nugraha. 2007. "Analysis of Determining Target Accuracy of Rocket Launchers on Xbee-Pro based Wheeled Robots to Realize the Development of Technology on the Military Field," Journal of Electronics, Electromedical Engineering, and Medical Informatics. 2(3). 4-6.

[10] D. P. AT Nugraha. 2020. "Prototype Hybrid Power Plant of Solar Panel and Vertical Wind Turbine as a Provider of Alternative Electrical Energy at Kenjeran Beach Surabaya," Journal of Electronics, Electromedical Engineering, and Medical Informatics. 2(3). 4-6.

[11] Umanand, Prof. L., 2007, Non-Conventional Energy Systems. Bangalore : Indian Institute of Science Bangalore.

[12] Tong, C.W., 1997, The Design And Testing Of A Wind Turbin For Malaysian Wind Condition. Madura: UTM.

[13] Hilloowala, Rohin M., and Adel M. Sharaf. "A rule-based fuzzy logic controller for a PWM inverter in a stand alone wind energy conversion scheme." IEEE Transactions on Industry Applications 32, no. 1 (1996): 57-65.

[14] Anonim 3, 2012, Keuntungan Kerugian Angin. www.surya.co.id. (accessed January 2, 2021)

[15] Manwell, J.F ., 2002. Wind Energy Explained Theory, Design and Application. Amherst : John Wiley and Sons, Ltd. 